\title{
Phytochemicals, Antioxidant and Antidiabetic Activities of Extracts from Miliusa velutina Flowers
}

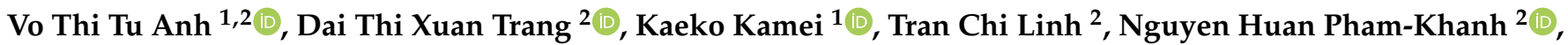 \\ Nguyen Trong Tuan ${ }^{2}$ and Luu Thai Danh ${ }^{3, *}$
}

1 Department of Biomolecular Engineering, Kyoto Institute of Technology, Matsugasaki, Sakyo, Kyoto 606-8585, Japan; vttanh@ctu.edu.vn (V.T.T.A.); kame@kit.ac.jp (K.K.)

2 College of Natural Sciences, Can Tho University, Can Tho City 94000, Vietnam; dtxtrang@ctu.edu.vn (D.T.X.T.); tclinh@ctu.edu.vn (T.C.L.); pknhuan@ctu.edu.vn (N.H.P.-K.); trongtuan@ctu.edu.vn (N.T.T.)

3 College of Agriculture, Can Tho University, Can Tho City 94000, Vietnam

* Correspondence: 1tdanh@ctu.edu.vn; Tel.: +84-931066222

Citation: Anh, V.T.T.; Trang, D.T.X.; Kamei, K.; Linh, T.C.; Pham-Khanh, N.H.; Tuan, N.T.; Danh, L.T. Phytochemicals, Antioxidant and Antidiabetic Activities of Extracts from Miliusa velutina Flowers. Horticulturae 2021, 7, 555. https://doi.org/10.3390/ horticulturae7120555

Academic Editors: Jelena Popović-Djordjević and Luiz Fernando Cappa de Oliveira

Received: 10 November 2021 Accepted: 2 December 2021 Published: 7 December 2021

Publisher's Note: MDPI stays neutral with regard to jurisdictional claims in published maps and institutional affiliations.

Copyright: (c) 2021 by the authors. Licensee MDPI, Basel, Switzerland. This article is an open access article distributed under the terms and conditions of the Creative Commons Attribution (CC BY) license (https:// creativecommons.org/licenses/by/ $4.0 /)$.

\begin{abstract}
The flowers of M. velutina were extracted with ethanol to obtain a crude extract that was consecutively extracted using n-hexane, dichloromethane, ethyl acetate and water. The crude extract and fractions were studied for the chemical composition and antioxidant and antidiabetic activities. The extracts had various phytoconstituents, namely steroids, flavonoids, tannins, saponins, alkaloids and glycosides. The aqueous extract had the highest total polyphenol (12.6 mg GAE/g extract) and total flavonoid (205.6 mg QE/g extract) content. The aqueous extract exhibited the strongest antioxidant activities in the ferric reducing antioxidant power assay $\left(\mathrm{EC}_{50}=4.0 \mu \mathrm{g} / \mathrm{mL}\right)$, reducing power assay $\left(\mathrm{EC}_{50}=78.1 \mu \mathrm{g} / \mathrm{mL}\right), 2$,2-azino-bis-3-ethylbenzothiazoline-6-sulphonic acid radical cation assay $\left(\mathrm{EC}_{50}=48.2 \mu \mathrm{g} / \mathrm{mL}\right)$, total antioxidant capacity assay $\left(\mathrm{EC}_{50}=8.7 \mu \mathrm{g} / \mathrm{mL}\right)$ and 1,1-diphenyl-2-picrylhydrazyl assay $\left(\mathrm{EC}_{50}=9.3 \mu \mathrm{g} / \mathrm{mL}\right)$. The aqueous extract showed the strongest inhibitory effect on the activity of $\alpha$-amylase $\left(\mathrm{IC}_{50}=376.6 \mu \mathrm{g} / \mathrm{mL}\right)$ and $\alpha$-glucosidase $\left(\mathrm{IC}_{50}=69.7 \mu \mathrm{g} / \mathrm{mL}\right)$. The results showed that the aqueous extract of $M$. velutina flowers can be a promising candidate for the control of diabetes and oxidative stress. This is the first report about the chemical components and antioxidant and antidiabetic activities of M. velutina flower extracts.
\end{abstract}

Keywords: antidiabetic; antioxidant; flavonoids; flower extract; Miliusa velutina; polyphenols

\section{Introduction}

Diabetes is a chronic systemic disease that is often associated with hyperglycemia, hyperinsulinemia and hypertriglyceridemia [1]. One of the treatments for diabetes management is to slow down the absorption of postprandial glucose by inhibiting $\alpha$-amylase and $\alpha$-glucosidase, two enzymes responsible for the hydrolysis of carbohydrate [2]. Natural products can be efficiently used as inhibitors of these enzymes and often have less side effects than synthetic drugs [3]. The impaired glucose metabolism results in excessive production of free radicals and consequently enhances oxidative stress in the body. In recent years, free radical action has been found to cause partial or complete damage of essential molecules in cells, which in turn induces several aging-related and chronic diseases, namely cancer, heart disease, cataracts and Alzheimer's disease [4]. Antioxidants were demonstrated to have a protective effect against free radicals. Consequently, antioxidant therapy has been emerging as a promising treatment for the management of aging and chronic diseases.

A significant number of chemical compounds derived from plants are considered to be potential pharmaceutical sources for the treatment of various diseases [5-8]. For drug development, bioactive compounds originating from plants, such as flavonoids, tannins, polyphenols and alkaloids, play vital roles. Miliusa velutina is an edible medicinal plant in 
Vietnam. M. velutina is used in traditional medicine for the treatment of various diseases, namely inflammation and bacterial infections. The plant was demonstrated to exhibit antibacterial and anti-cytotoxicity activities [9]. In our previous studies, extracts from the leaves and stem barks of $M$. velutina were demonstrated to have strong antioxidant as well as antidiabetic [10] and hepatoprotective [11] activities. The fruits and flowers of $M$. velutina were demonstrated to contain homogentisic acid derivatives that showed antibacterial activity [12]. However, the biochemical properties and hypoglycemic effects of extracts from M. velutina flowers have been not studied thoroughly. In addition, certain bioactive compounds from $M$. velutina flowers can be effectively extracted using a solvent with an appropriate polarity. In this study, the flowers of $M$. velutina were initially extracted using ethanol to achieve a crude extract, which was then extracted using solvents with increasing polarity (n-hexane, dichloromethane, ethyl acetate and water). The chemical composition and antioxidant and antidiabetic activities of the extracts were compared to find the best extract with the strongest biological activities.

\section{Materials and Methods}

\subsection{Plant Preparation and Extraction}

Flowers, leaves and stems of Miliusa velutina were collected from mature plants at Nui Cam mountain, An Giang province, Vietnam (Figure 1). The plant was identified and deposited (voucher specimen: AG_Mi201906040005) at the Laboratory of Plants and Animals, College of Natural Sciences, Can Tho University.

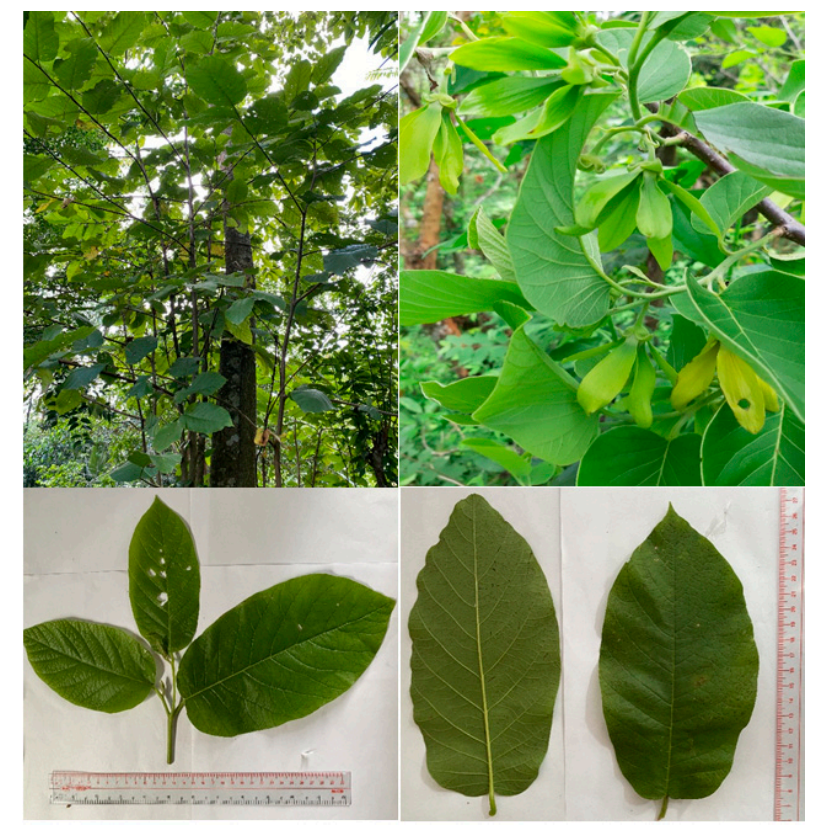

Figure 1. Flowers, leaves and stems of Miliusa velutina plant.

Plant materials were extracted and fractionated using the method described in the study of Kitzberger et al. [13] with some modifications. Flower powder ( $200 \mathrm{~g})$ was soaked in $2 \mathrm{~L}$ of $96 \%$ ethanol for $24 \mathrm{~h}$ at room temperature and filtered using Whatman No. 1 paper. The extraction was repeated three times. The combined ethanol extracts were evaporated to dryness to obtain $68.13 \mathrm{~g}$ crude extract. The crude (ethanolic) extract $(20 \mathrm{~g})$ was well mixed with water $(500 \mathrm{~mL})$ followed by consecutive extraction with hexane $(500 \mathrm{~mL})$, dichloromethane $(500 \mathrm{~mL})$ and ethyl acetate $(500 \mathrm{~mL})$ to give a hexane extract $(1.30 \mathrm{~g})$, dichloromethane extract (5.2 g) and ethyl acetate extract (5.8 g), respectively. The remaining water layer was condensed to obtain an aqueous extract $(6.10 \mathrm{~g})$. 


\subsection{Phytochemical Screening}

The crude and fractional extracts of $M$. velutina flowers were qualitatively screened for alkaloids, flavonoids, steroids, tannins, saponins and glycosides using the methods of Biswas et al. [14].

\subsubsection{Determination of Total Polyphenol Content}

The total phenolic content of the plant extracts was assessed using the Folin-Ciocalteu method [15]. In brief, $250 \mu \mathrm{L}$ of the extract solution with a concentration of $100 \mu \mathrm{g} / \mathrm{mL}$ was mixed with $250 \mu \mathrm{L}$ distilled water and $250 \mu \mathrm{L}$ Folin-Ciocalteu reagent. After $10 \mathrm{~min}$, $250 \mu \mathrm{L}$ of $10 \% \mathrm{Na}_{2} \mathrm{CO}_{3}$ was added and incubated at $40{ }^{\circ} \mathrm{C}$ for $30 \mathrm{~min}$. The samples were spectrophotometrically measured at $765 \mathrm{~nm}$. The standard was gallic acid, and the results are expressed as $\mathrm{mg}$ of gallic acid equivalent per $\mathrm{g}$ of extract.

\subsubsection{Determination of Total Flavonoid Content}

The total flavonoid content of $M$. velutina extracts was determined using the method reported in the study of Bag et al. [16] with modifications. Briefly, $200 \mu \mathrm{L}$ extract solution in methanol $(100 \mu \mathrm{g} / \mathrm{mL})$ was mixed with $200 \mu \mathrm{L}$ distilled water and $40 \mu \mathrm{L}$ of $5 \% \mathrm{NaNO}_{2}$ and then left for $5 \mathrm{~min}$. Next, $40 \mu \mathrm{L}$ of $10 \% \mathrm{AlCl}_{3}$ was added in the mixture and incubated for $6 \mathrm{~min}$. Subsequently, $400 \mu \mathrm{L}$ of $1 \mathrm{M} \mathrm{NaOH}$ was added. Finally, the solution was mixed with $120 \mu \mathrm{L}$ of distilled water and spectrophotometrically measured at $510 \mathrm{~nm}$. The standard was quercetin, and the results are expressed as $\mathrm{mg}$ of quercetin equivalent per $\mathrm{g}$ of extract.

\subsection{Assays of Antioxidant Activities}

\subsubsection{1,1-Diphenyl-2-picrylhydrazyl (DPPH) Assay}

The DPPH assay was adapted from Sharma and Bhat [17] with modifications. Briefly, $960 \mu \mathrm{L}$ of various extract concentrations in methanol was mixed with $40 \mu \mathrm{L}$ methanolic solution of $1000 \mu \mathrm{g} / \mathrm{mL}$ DPPH radicals. A blank control was also implemented by adding $960 \mu \mathrm{L}$ of methanol in $40 \mu \mathrm{L}$ DPPH solution. A standard antioxidant, Trolox, was tested for comparison. The mixtures were left in the dark for $30 \mathrm{~min}$ and spectrophotometrically measured at $517 \mathrm{~nm}$. DPPH scavenging activity was expressed as inhibition percentage of the extract samples on free radicals by the following equation: \% Inhibition of DPPH $=(\mathrm{Ac}-\mathrm{At}) / \mathrm{Ac} \times 100$, where Ac and At are the absorbances of the blank control and the sample, respectively. The assay was repeated three times for each extract concentration. The $\mathrm{EC}_{50}$ value of the extracts was determined as their effective concentrations required to scavenge $50 \%$ of the DPPH present in the test solution.

\subsubsection{2,2-Azino-bis-3-ethylbenzothiazoline-6-sulphonic Acid $\left(\right.$ ABTS $\left.^{\bullet+}\right)$ Assay}

$\mathrm{ABTS}^{\bullet+}$ assay was performed using the method reported in the study of Nenadis et al. [18]. A solution containing $7 \mathrm{mM}$ ABTS solution and $2.45 \mathrm{mM}$ potassium persulfate (the final concentrations) was mixed and left in the dark for 12-16 h at room temperature. This solution was then diluted using ethanol to obtain an absorbance of $0.70 \pm 0.05$ at $734 \mathrm{~nm}$. An amount of $10 \mu \mathrm{L}$ of the extracts and the standard in different concentrations dissolved in $10 \%$ DMSO was added to $990 \mu \mathrm{L}$ of the diluted $\mathrm{ABTS}^{\bullet+}$ solution, mixed thoroughly and left for $6 \mathrm{~min}$. The solutions were spectrophotometrically read at $734 \mathrm{~nm}$. The percentage of inhibition of the ABTS was calculated in a similar way to that in the DPPH radical scavenging assay. The assay was repeated three times for each extract concentration. ABTS scavenging activity is shown as an $\mathrm{EC}_{50}$ value.

\subsubsection{Reducing Power (RP) Capacity Assessment}

$\mathrm{RP}$ capacity was determined by using the modified method reported in the study of Oyaizu [19]. Briefly, $500 \mu \mathrm{L}$ solution of plant extracts with various concentrations was mixed with $500 \mu \mathrm{L}$ of potassium buffer $(0.2 \mathrm{M}, \mathrm{pH}$ 6.6) and $500 \mu \mathrm{L}$ of potassium ferricyanide $\left(\mathrm{K}_{3} \mathrm{Fe}(\mathrm{CN})_{6}\right)(1 \%)$ solution. The solution was incubated at $50{ }^{\circ} \mathrm{C}$ for $20 \mathrm{~min}$, and then, $500 \mu \mathrm{L}$ of $10 \%$ trichloroacetic acid solution was added to the mixture. The solution was centrifuged 
for $10 \mathrm{~min}$ at $3000 \times \mathrm{g}$. Subsequently, $500 \mu \mathrm{L}$ supernatant was taken and mixed with $100 \mu \mathrm{L}$ of $0.1 \% \mathrm{FeCl}_{3}$ solution and $500 \mu \mathrm{L}$ distilled water. The solution was spectrophotometrically measured at $700 \mathrm{~nm}$. Finally, the antioxidant activity was determined by using the Trolox standard curve and is expressed in $\mu \mathrm{g} / \mathrm{mL}$ Trolox. The assay was repeated three times for each extract concentration. The $\mathrm{EC}_{50}$ of the extracts is the concentration at which the absorbance was 0.50 [20].

\subsubsection{Ferric Reducing Antioxidant Power (FRAP) Assay}

The FRAP of the extracts was evaluated using the method of Benzie and Strain [21] with modifications. In brief, FRAP reagent solution, containing $0.25 \mathrm{~mL}$ of $20 \mathrm{mM} \mathrm{FeCl}_{3}$, $2.5 \mathrm{~mL}$ of $10 \mathrm{mM}$ TPTZ solution in $40 \mathrm{mM} \mathrm{HCl}$ and $2.5 \mathrm{~mL}$ of $0.2 \mathrm{M}$ acetate buffer $(\mathrm{pH}=3.6)$, was freshly prepared and incubated at $37^{\circ} \mathrm{C}$. Then, $10 \mu \mathrm{L}$ of the extracts with different concentrations was mixed with $990 \mu \mathrm{L}$ of FRAP reagent and left at room temperature for half an hour. The solution was spectrophotometrically measured at $593 \mathrm{~nm}$. $\mathrm{EC}_{50}$ is the extract concentration that had an absorbance of 0.50 [20]. The assay was repeated three times for each extract concentration. The antioxidant activity was calculated from the Trolox standard curve and is expressed in $\mu \mathrm{g} / \mathrm{mL}$ Trolox.

\subsubsection{Total Antioxidant Capacity (TAC) Assay}

The TAC of the extracts was determined using the phosphomolybdate assay [22]. Briefly, $300 \mu \mathrm{L}$ of the extract solution with different concentrations was added in $900 \mu \mathrm{L}$ of reagent solution containing $4 \mathrm{mM}$ ammonium molybdate, $0.6 \mathrm{M}$ sulfuric acid and $28 \mathrm{mM}$ sodium phosphate. The solutions were incubated at $95{ }^{\circ} \mathrm{C}$ for $1.5 \mathrm{~h}$ in the dark. The samples were spectrophotometrically recorded at $695 \mathrm{~nm}$ as the samples cooled to room temperature. $\mathrm{EC}_{50}$ is the extract concentration that had an absorbance of 0.50 [20]. The assay was repeated three times for each extract concentration. Finally, the antioxidant activity was calculated using the Trolox standard curve and is expressed in $\mu \mathrm{g} / \mathrm{mL}$ Trolox.

\subsection{Antidiabetic Activity Tests}

\subsubsection{Alpha-Amylase Inhibitory Assay}

The assay was performed by using the method reported in the study of Rana et al. [23] with modifications. Initially, $50 \mu \mathrm{L}$ of the extract or acarbose (a well-known $\alpha$-amylase inhibitor) solution in $0.2 \mathrm{M}$ phosphate buffer $(\mathrm{pH}=7.0)$ was mixed with $50 \mu \mathrm{L}$ enzyme $\alpha$-amylase solution $(3 \mathrm{U} / \mathrm{mL})$ and left for $15 \mathrm{~min}$ at $37^{\circ} \mathrm{C}$. Subsequently, starch solution $(2 \mathrm{mg} / \mathrm{mL})$ at a volume of $50 \mu \mathrm{L}$ was added into the mixture and incubated for $15 \mathrm{~min}$ at $37^{\circ} \mathrm{C}$. Then, the reaction was stopped by adding $200 \mu \mathrm{L} \mathrm{HCl}$. Finally, $300 \mu \mathrm{L}$ of $1 \%$ iodine solution was added to the mixture. The mixture was spectrophotometrically recorded at $660 \mathrm{~nm}$. The assay was repeated three times for each extract concentration. Alpha-amylase inhibitory activity was calculated using the following formula:

$$
(\%) \text { Inhibition }=\left[1-\left(\mathrm{Abs}_{\text {sample }} / \mathrm{Abs}_{\mathrm{control}}\right)\right] \times 100
$$

where $\mathrm{Abs}_{\text {control }}$ and $\mathrm{Abs}_{\text {sample }}$ represent the absorbance of the control (without the extracts or acarbose) and the plant extract or acarbose, respectively. The $\mathrm{IC}_{50}$ value is the sample concentration providing $50 \%$ inhibition.

\subsubsection{Alpha-Glucosidase Inhibitory Assay}

The assay was carried out using the procedure reported in the study of Pujirahayu et al. [24] with modifications. Here, p-nitrophenyl $\alpha$-glucopyranoside (pNPG) was used as a substrate. The reaction mixture, containing $100 \mu \mathrm{L}$ phosphate buffer (100 mM, pH 6.8), $20 \mu \mathrm{L}$ $\alpha$-glucosidase enzyme $(1 \mathrm{U} / \mathrm{mL})$ and $40 \mu \mathrm{L}$ plant extract or acarbose solution, was left for $15 \mathrm{~min}$ at $37^{\circ} \mathrm{C}$. Subsequently, $40 \mu \mathrm{L}$ pNPG $(5 \mathrm{mM})$ solution was added and left for $20 \mathrm{~min}$ at $37^{\circ} \mathrm{C}$. The reaction was terminated by adding a solution of $\mathrm{Na}_{2} \mathrm{CO}_{3}(0.1 \mathrm{M}, 100 \mu \mathrm{L})$. The mixture was spectrophotometrically measured at $405 \mathrm{~nm}$. The assay was repeated 
three times for each extract concentration. The inhibition of extracts on $\alpha$-glucosidase was calculated as follows:

$$
(\%) \text { Inhibition }=\left[1-\left(\mathrm{Abs}_{\text {sample }} / \mathrm{Abs}_{\mathrm{control}}\right)\right] \times 100
$$

where $\mathrm{Abs}_{\text {control }}$ and $\mathrm{Abs}_{\text {sample }}$ represent the absorbance of the control (without the extracts or acarbose) and the plant extract or acarbose, respectively. The $\mathrm{IC}_{50}$ value is the sample concentration providing $50 \%$ inhibition.

\subsection{Statistical Analysis}

Data were analyzed by analysis of variance (ANOVA) and Fisher's test using Minitab 16.0 software. The results were statistically significantly different at $p<0.05$.

\section{Results}

\subsection{Chemical Composition}

The chemical analysis of five extracts from $M$. velutina flowers showed the presence of alkaloids, flavonoids, tannins and steroids (Table 1), while saponins and glycosides were only present in the ethanol and aqueous extracts. The polarity index of the extracting solvents can be ranked in decreasing order as follows: water (9), ethanol (5.2), ethyl acetate (4.3), dichloromethane (3.4) and hexane (0). The results indicate that alkaloids, flavonoids, tannins and steroids can be soluble in both polar and non-polar solvents, while only highly polar solvents can solubilize glycosides and saponins.

Table 1. Chemical compounds in the crude extract and fractions.

\begin{tabular}{ccccccc}
\hline Extracts & Alkaloids & Flavonoids & Tannins & Glycosides & Steroids & Saponins \\
\hline Ethanol extract (crude) & + & + & + & + & + & + \\
n-Hexane fraction & + & + & + & - & + & + \\
Dichloromethane fraction & + & + & + & - & + & + \\
Ethyl acetate fraction & + & + & + & + & + & + \\
Aqueous fraction & + & + & + & & + \\
\hline
\end{tabular}

Note: +, present; -, absent.

The total polyphenol and flavonoid contents of the crude extract and extract fractions obtained from the flowers of $M$. velutina are presented in Table 2. The aqueous and n-hexane fractions exhibited the highest $(12.6 \pm 0.1 \mathrm{mg} / \mathrm{g})$ and lowest $(4.72 \pm 0.23 \mathrm{mg} / \mathrm{g})$ total contents of polyphenol, respectively. Similarly, the flavonoid content was the highest $(205.6 \pm 39.0 \mathrm{mg} / \mathrm{g})$ and the lowest $(71.2 \pm 4.5 \mathrm{mg} / \mathrm{g})$ in the aqueous and $\mathrm{n}$-hexane fractions, respectively.

Table 2. The total polyphenol and flavonoid contents in M. velutina flower extracts.

\begin{tabular}{ccc}
\hline Extracts & Polyphenol (mg Gallic Acid/g Extract) & Flavonoid (mg Quercetin/g Extract) \\
\hline Ethanol extract (crude) & $8.0^{\mathrm{b}} \pm 0.1$ & $172.2 \pm 3.1$ \\
n-Hexane fraction & $4.7^{\mathrm{c}} \pm 0.2$ & $71.18^{\mathrm{d}} \pm 4.5$ \\
Dichloromethane fraction & $5.1^{\mathrm{c}} \pm 0.1$ & $132.07^{\mathrm{c}} \pm 16.03$ \\
Ethyl acetate fraction & $9.2^{\mathrm{a}} \pm 0.1$ & $185.92^{\mathrm{b}} \pm 5.82$ \\
Aqueous fraction & $12.6^{\mathrm{a}} \pm 0.1$ & $205.58^{\mathrm{a}} \pm 38.98$ \\
\hline
\end{tabular}

Note: Different letters in the same column show significant difference at level of $5 \%$.

\subsection{Antioxidant Assays}

The DPPH assay is one of the most popular methods for the determination of antioxidant activity [25], and the DPPH scavenging activity observed in all extracts increased with the concentration of extracts (Figure 2a). In this study, the aqueous extract, with an $\mathrm{EC}_{50}$ value of $59.1 \pm 1.0 \mu \mathrm{g} / \mathrm{mL}$, showed the highest scavenging activity. Meanwhile, the n-hexane extract exhibited the lowest activity with an $\mathrm{EC}_{50}$ value of $188.9 \pm 3.7 \mu \mathrm{g} / \mathrm{mL}$ 
(Table 3). A lower $\mathrm{EC}_{50}$ value shows higher antioxidant activity. All extracts had dosedependent DPPH scavenging activity (Figure 2a).

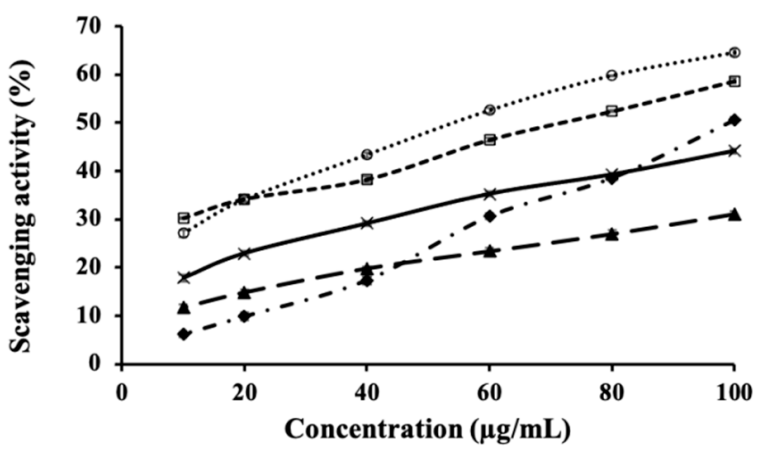

(a)

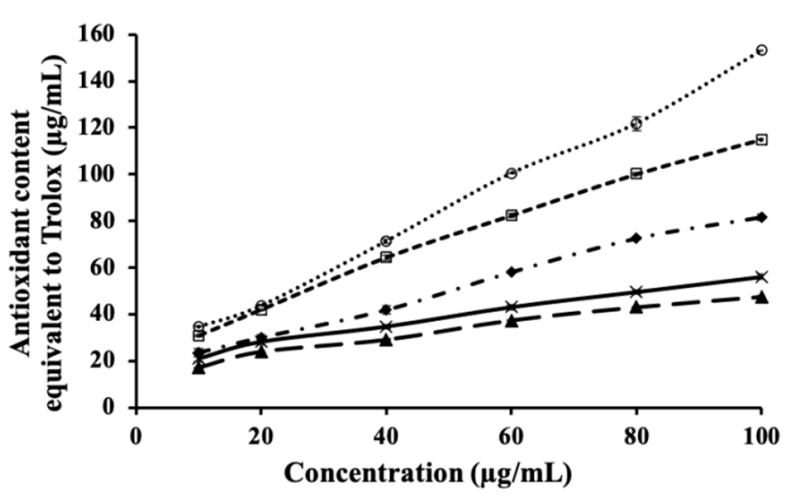

(c)

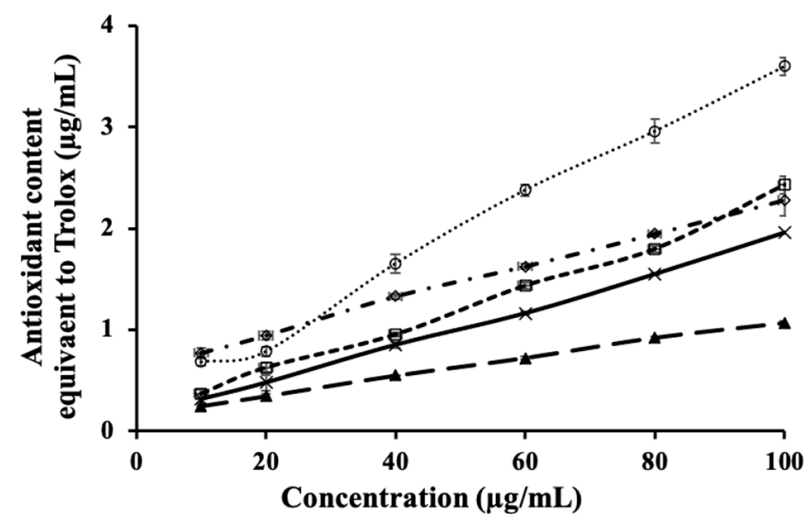

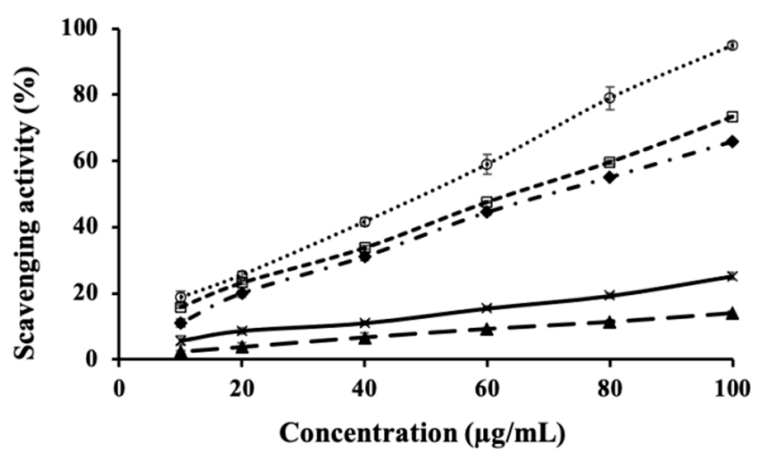

(b)

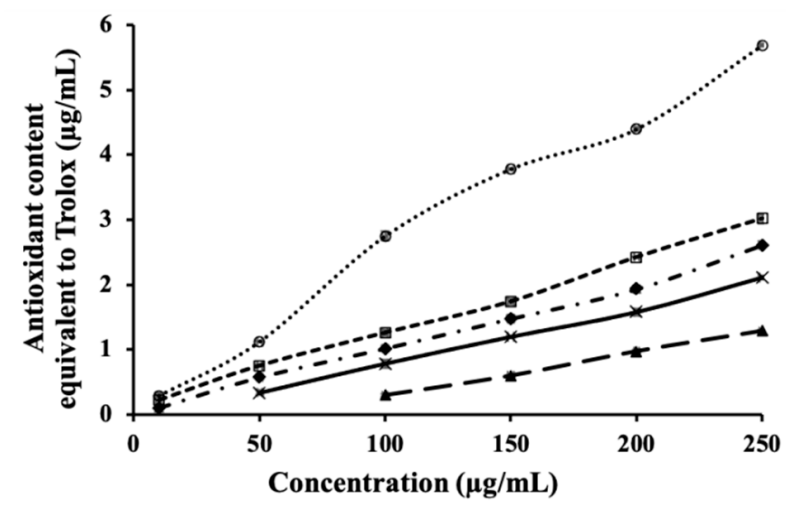

(d)

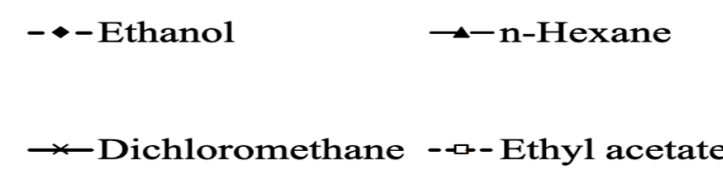

No... Aqueous

(e)

Figure 2. The antioxidant activities of the different extracts of M. velutina flowers in five assays: (a) DPPH, (b) ABTS, (c) TAC, (d) FRAP and (e) RP.

Table 3. Antioxidant activities $\left(\mathrm{EC}_{50}\right)$ of $M$. velutina flower extracts.

\begin{tabular}{|c|c|c|c|c|c|}
\hline \multirow{2}{*}{ Extracts } & \multicolumn{5}{|c|}{$\mathrm{EC}_{50}(\mu \mathrm{g} / \mathrm{mL})$} \\
\hline & ABTS $\bullet+$ & DPPH & $\mathbf{R P}$ & TAC & FRAP \\
\hline Crude extract (ethanol) & $71.7^{\mathrm{c}} \pm 0.9$ & $101.0^{\mathrm{c}} \pm 0.7$ & $193.7^{c} \pm 2.2$ & $27.5^{\mathrm{d}} \pm 1.0$ & $64.9^{c} \pm 0.9$ \\
\hline n-Hexane fraction & $377.0^{\mathrm{a}} \pm 10.3$ & $188.9^{\mathrm{a}} \pm 3.7$ & $346.7^{\mathrm{a}} \pm 4.6$ & $57.8^{\mathrm{a}} \pm 0.4$ & $154.3^{\mathrm{a}} \pm 0.9$ \\
\hline Dichloromethane fraction & $225.1^{b} \pm 3.1$ & $117.0^{\mathrm{b}} \pm 1.3$ & $232.6^{b} \pm 9.5$ & $42.0^{\mathrm{b}} \pm 0.2$ & $80.5^{b} \pm 0.8$ \\
\hline Ethyl acetate fraction & $63.9^{\mathrm{c}} \pm 0.5$ & $72.7^{\mathrm{d}} \pm 1.2$ & $158.0^{\mathrm{d}} \pm 2.4$ & $11.9^{\mathrm{e}} \pm 0.3$ & $56.5^{\mathrm{d}} \pm 1.7$ \\
\hline Aqueous fraction & $48.1^{\mathrm{d}} \pm 0.7$ & $59.1^{\mathrm{e}} \pm 1.0$ & $78.07^{\mathrm{e}} \pm 1.1$ & $11.8^{\mathrm{e}} \pm 0.1$ & $38.5^{\mathrm{e}} \pm 1.1$ \\
\hline Trolox & $3.3^{\mathrm{e}} \pm 0.1$ & $0.7^{\mathrm{f}} \pm 0.01$ & $1.92^{\mathrm{f}} \pm 0.11$ & $35.0^{\mathrm{c}} \pm 0.4$ & $1.6^{\mathrm{f}} \pm 0.0$ \\
\hline
\end{tabular}

Note: Different letters in the same column show significant difference at level of $5 \%$. 
ABTS scavenging ability was observed, in descending order, in the aqueous, ethyl acetate, ethanol, dichloromethane and n-hexane fractions at all tested concentrations (Figure $2 \mathrm{~b}$ ). The ABTS scavenging ability of the extracts was positively proportional to the concentration of the tested extracts.

In the TAC assay, Mo (VI) was reduced to Mo (V) by reducing compounds from the extracts, leading to the formation of the green phosphate/Mo (V) complex that was spectrophotometrically recorded at $695 \mathrm{~nm}$. The result is expressed as the antioxidant content equivalent to Trolox (Figure 2c). The TAC of the aqueous extract was the highest at each concentration tested, followed in descending order by the ethyl acetate, ethanol (crude), dichloromethane and hexane extracts.

Ferric iron $\left(\mathrm{Fe}^{3+}\right)$ was reduced to ferrous iron $\left(\mathrm{Fe}^{2+}\right)$ by reducing compounds from the extracts in the FRAP assay [23]. The reduction of $\mathrm{Fe}^{3+}$ by the extracts increased with the extract concentration (Figure 2d). The $\mathrm{EC}_{50}$ values of the extracts based on FRAP assay are shown in Table 3. The highest antioxidant capacity was in the aqueous extract, followed by the ethyl acetate, ethanol (crude), dichloromethane and n-hexane extracts.

The RP assay was used to determine the ability of the compounds from the extracts to donate electrons. The electron donation of extracts leads to the conversion of $\mathrm{Fe}^{3+}$ to $\mathrm{Fe}^{2+}$. The $\mathrm{Fe}^{2+}$ complex (Perl's Prussian blue) concentration can be spectrophotometrically determined at $700 \mathrm{~nm}$. Higher absorbance at $700 \mathrm{~nm}$ is due to higher reducing power. The reducing power of the extracts increased with the extract concentration (Figure 2e). The reducing power of the aqueous extract was the highest, followed by the ethyl acetate, ethanol (crude), dichloromethane and hexane extracts.

Trolox showed the strongest antioxidant activities as compared to all plant extracts in four antioxidant activity assays, namely DDPH, ABTS, FRAP and RP (Table 3). However, the ethyl acetate and aqueous fractions had higher antioxidant activity than that of Trolox in the TAC assay. The $\mathrm{EC}_{50}$ value of Trolox and the aqueous and ethyl acetate fractions in TAC assay was $35.0 \pm 0.4,11.8 \pm 0.1$ and $11.9 \pm 0.3 \mu \mathrm{g} / \mathrm{mL}$, respectively.

\subsection{Carbohydrate Digesting Enzyme Inhibition Potential}

The inhibitory activity of the extracts against $\alpha$-amylase and $\alpha$-glucosidase increased with the extract concentrations (Figure 3a,b). Among the five extracts, the aqueous fraction had the strongest inhibitory activity against these enzymes at each tested concentration, followed by the ethyl acetate, ethanol (crude), dichloromethane and hexane extracts.

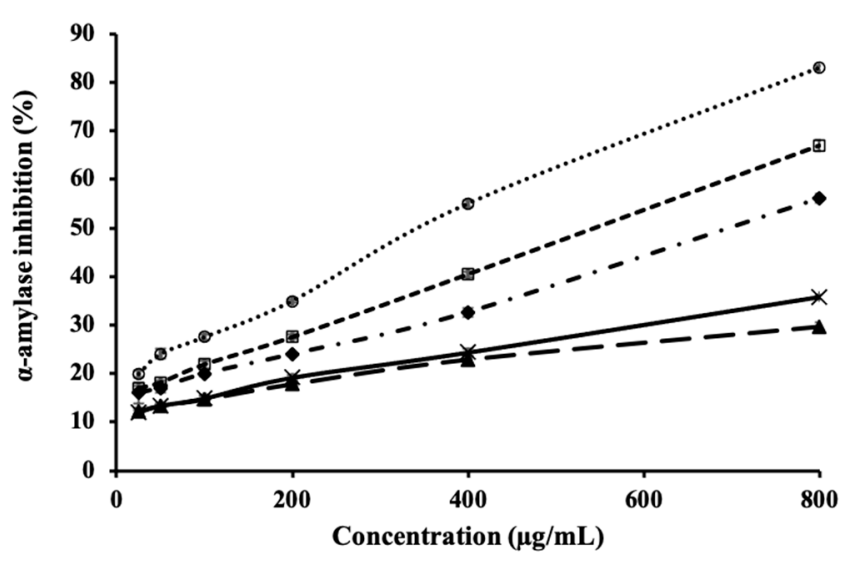

$-\bullet-$ Ethanol $\rightarrow-$ n-Hexane $\quad *$ Dichloromethane

(a)

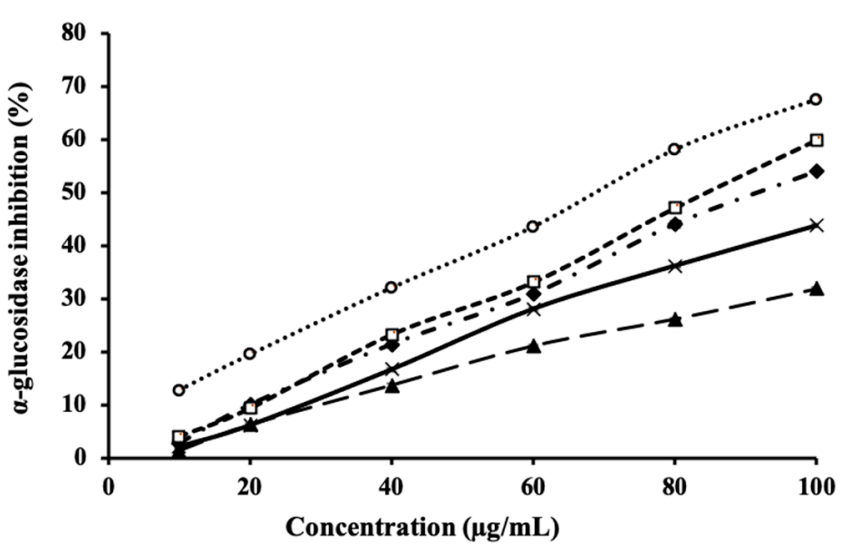

- - Ethyl acetate $\quad \cdots \circ \cdots$ Aqueous

(b)

Figure 3. The percentage inhibition of $\alpha$-amylase (a) and $\alpha$-glucosidase (b) by the different extracts of M. velutina flowers. 
The aqueous extract showed the strongest $\alpha$-amylase and $\alpha$-glucosidase inhibitory activities with $\mathrm{IC}_{50}$ values of $376.6 \pm 5.2$ and $69.7 \pm 0.3 \mu \mathrm{g} / \mathrm{mL}$, respectively (Table 4). The ethanol, n-hexane, dichloromethane and ethyl acetate extracts showed moderate inhibitory effects against these enzymes. The $\mathrm{IC}_{50}$ value of acarbose (a standard reference drug) for $\alpha$-amylase and $\alpha$-glucosidase was very low at $12.1 \pm 0.2$ and $6.7 \pm 0.1 \mu \mathrm{g} / \mathrm{mL}$, respectively, indicating that acarbose is very effective in inhibiting these enzymes.

Table 4. Enzyme inhibitory activity $\left(\mathrm{IC}_{50}\right)$ of $M$. velutina flower extracts.

\begin{tabular}{|c|c|c|}
\hline \multirow{2}{*}{ Extracts } & \multicolumn{2}{|c|}{$\mathrm{IC}_{50}(\mu \mathrm{g} / \mathrm{mL})$} \\
\hline & $\alpha$-amylase & $\alpha$-glucosidase \\
\hline Ethanol extract (crude) & $701.5^{c} \pm 13.4$ & $92.2^{\mathrm{c}} \pm 13.4$ \\
\hline n-Hexane fraction & $1675.1^{\mathrm{a}} \pm 40.8$ & $150.7^{\mathrm{a}} \pm 40.8$ \\
\hline Dichloromethane fraction & $1258.0^{b} \pm 32.5$ & $110.3^{\mathrm{b}} \pm 0.5$ \\
\hline Ethyl acetate fraction & $541.1^{\mathrm{d}} \pm 11.8$ & $84.8^{\mathrm{d}} \pm 0.3$ \\
\hline Aqueous fraction & $376.6^{\mathrm{e}} \pm 5.2$ & $69.7^{\mathrm{e}} \pm 0.3$ \\
\hline Acarbose & $12.1^{\mathrm{f}} \pm 0.2$ & $6.7^{\mathrm{f}} \pm 0.1$ \\
\hline
\end{tabular}

Note: Different letters in the same column show significant difference at level of $5 \%$.

\section{Discussion}

Generally, the total polyphenol and flavonoid content in the fractions increased in the following order: n-hexane, dichloromethane, ethyl acetate and aqueous fraction (Table 2). The higher polarity of the extracting solvents may have induced the higher solubility of polyphenols and flavonoids (except flavonoid aglycones not soluble in water, which is a highly polar solvent) in the extracting solution. Clearly, solvent polarity increases in the following order: hexane, dichloromethane, ethyl acetate and water. Several studies also indicated that the solubility of polyphenol and flavonoid compounds in extracting solvents depends on their polarity [26-28]. The crude extract in this study contained both water-soluble and non-soluble flavonoids that were consecutively extracted by non(hexane) and low-polar solvents (dichloromethane and ethyl acetate). The high content of flavonoids in the aqueous fraction (Table 2) constituted the remaining flavonoids that were not effectively extracted by the non- and low-polar solvents and was not due to the flavonoid-extracting ability of water.

The total polyphenol content of Miliusa velutina flower extract and fractions was significantly lower than the total flavonoid content (Table 2). Flavonoids are a subgroup of polyphenols; therefore, the total polyphenol content in extracts is commonly expected to be higher than the total flavonoids. It was clearly demonstrated in the study of Kim et al. [29] that extracts from 40 plant species in Korea had a higher content of total polyphenol than of total flavonoids. However, the total polyphenol content was observed to be lower than the total flavonoid content in the extracts of other plant species and green algae [30-32]. The lower content of total polyphenols than that of total flavonoids observed in this study can be explained by two reasons. The total content of flavonoids in the flowers of Miliusa velutina is actually higher than that of polyphenols. This is supported by the study of Son [33] where 43 flavonoid compounds were identified from the plant parts of Miliusa species, including Miliusa velutina, while only 13 polyphenolic compounds were detected. In addition, differences in the specificity of the Folin-Ciocalteu and $\mathrm{AlCl} 3$ methods used to quantify the total polyphenol and total flavonoid contents, respectively, may be the second reason. Folin-Ciocalteu reagent is not highly specific, so it will react with not only polyphenols but also any reducing substances in samples [34]. While $\mathrm{AlCl} 3$ specifically targets the C-4 keto group and either the C-3 or C-5 hydroxyl group of flavones and flavonols to form acid-stable complexes, it also reacts with the ortho-dihydroxyl groups in the A- or B-ring of flavonoids to form acid-labile complexes [35]. In order to confirm the results about the total polyphenols and flavonoids content in this study, LCMS or LC-MS/MS analysis of the chemical composition of the extract and fractions from Miliusa velutina flowers could be performed. 
The total polyphenol and flavonoid contents in the extracts were positively proportional to the antioxidant activities. The antioxidant activity of the aqueous extract in five antioxidant activity assays (DPPH, FRAP, RP, TAC and ABTS) was the strongest, followed in descending order by ethyl acetate, ethanol (crude), dichloromethane and n-hexane extract (Figure 2). The same decreasing order was also observed in the polyphenol and flavonoid contents of these extracts (Table 2). Polyphenol and flavonoid compounds are strong antioxidants that can deactivate free radicals by offering their hydrogen atoms and electron [36]. The positive correlation between the total content of phenolic and flavonoid compounds in the plant extracts and the antioxidant activities was also observed in other studies [36].

The crude or ethanolic extract had lower antioxidant activities in the five antioxidant assays as compared to those of the ethyl acetate and aqueous fractions (Table 3). Polyphenols and flavonoids are polar and strong antioxidant compounds. The crude extract contained both polar and non-polar compounds that were consecutively extracted by n-hexane and dichloromethane (non-polar solvents). These fractionations resulted in the removal of undesired and non-polar compounds, which in turn helped to concentrate the polar compounds (including polyphenols and flavonoids) in subsequent fractionations (ethyl acetate and aqueous fractions). It is clearly indicated in Table 2 that the polyphenol and flavonoid contents of the ethyl acetate and aqueous fractions were higher than those of the crude extract. Consequently, the antioxidant activities of the ethyl acetate and aqueous fractions were higher than those of the crude extract.

Five different antioxidant assays were used in this study in order to determine the antioxidant activity of the extract and fractions from Miliusa velutina flowers over different types of oxidants. Each antioxidant assay represents a certain type of oxidant. In the human body, there is a wide range of oxidants, including free radicals, reactive oxygen species and reactive nitrogen species. The extract with strong activity against a wide range of oxidants would have great application potential. It can be seen from Table 2 that the flower extract and fractions had consistent activities against the five oxidants. The aqueous fraction had the strongest activity against the five tested oxidants.

The antidiabetic properties of M. velutina flower extracts were determined based on the inhibitory effect of two carbohydrate hydrolyzing enzymes in vitro, namely $\alpha$-amylase and $\alpha$-glucosidase. Starch is converted into disaccharides and oligosaccharides by pancreatic $\alpha$-amylase, while disaccharides are broken down into glucose by intestinal $\alpha$ glucosidase [37]. Enzymatic inhibition can retard the breakdown of starch in the gastrointestinal tract and therefore ameliorate hyperglycemia.

The aqueous fraction was also demonstrated to have the strongest inhibitory activity of both $\alpha$-amylase and $\alpha$-glucosidase as compared to that of the crude ethanolic extract and other extract fractions (Figure 3). The ability to inhibit these enzymes was positively correlated to the antioxidant ability of the extracts. Specifically, the stronger the antioxidant capacity was, the stronger the enzyme-inhibiting effect was. The results of this study are in agreement with the findings of other studies where strong antioxidants were also demonstrated to be strong $\alpha$-glucosidase and $\alpha$-amylase inhibitors [38,39]. The inhibitory activity of polyphenols against $\alpha$-amylase and $\alpha$-glucosidase relies on their chemical profile [40]. Flavonoids, one of the main classes of polyphenolic compounds, were demonstrated to have $\alpha$-amylase and $\alpha$-glucosidase inhibitory activity [41]. In terms of chemical structure, the location and number of hydroxyl groups in the compounds are crucial for enzyme inhibitory capacity. This capacity significantly increases with the number of hydroxyl groups on the B-ring. Flavonoids induce the inhibitory effect by forming hydrogen bonds between the hydroxyl groups of flavonoids and those of the enzyme at active side chains and forming the conjugated $\pi$ system between the AC ring system of flavonoids and the indole Trp59 in the enzyme. Consequently, the reaction between $\alpha$-amylase and starch would be hindered which would lead to the retardation of starch digestion [42].

The aqueous fraction of $M$. velutina flowers seems to be a promising candidate for the control of diabetes owing to its mild $\alpha$-amylase inhibitory effect $\left(\mathrm{IC}_{50}=376.6 \pm 5.2 \mu \mathrm{g} / \mathrm{mL}\right)$ 
and strong inhibitory effect against $\alpha$-glucosidase $\left(\mathrm{IC}_{50}=69.7 \pm 0.3 \mu \mathrm{g} / \mathrm{mL}\right)$ (Table 4$)$. A phytochemical that has mild and strong inhibitory effects against $\alpha$-amylase and $\alpha$-glucosidase, respectively, would be a desirable antidiabetic agent [43]. One of the main enzymes responsible for carbohydrate digestion and glucose release is $\alpha$-glucosidase. The inhibition of this enzyme can delay glucose absorption and lower the postprandial blood glucose level, which could, in turn, retard the progression of diabetes.

\section{Conclusions}

The crude extract as well as the derived fractions of $M$. velutina flowers were demonstrated to possess strong antioxidant properties. The extracts also mildly and strongly inhibited $\alpha$-amylase and $\alpha$-glucosidase in vitro, respectively. The antioxidant and antidiabetic activities of the M. velutina flower extracts were positively correlated to their polyphenol and flavonoid contents. The aqueous extract showed the highest antidiabetic as well as antioxidant activities.

Author Contributions: Conceptualization, L.T.D., V.T.T.A., K.K. and D.T.X.T.; methodology, V.T.T.A., N.T.T., N.H.P.-K. and D.T.X.T.; formal analysis, L.T.D., V.T.T.A., T.C.L. and N.T.T.; investigation, V.T.T.A., N.H.P.-K. and T.C.L.; data curation, L.T.D., V.T.T.A., K.K., D.T.X.T. and N.T.T.; writingoriginal draft preparation, L.T.D.; writing—review and editing, N.H.P.-K., K.K., N.T.T. and D.T.X.T.; supervision, L.T.D.; resources, L.T.D., N.T.T. and D.T.X.T. All authors have read and agreed to the published version of the manuscript.

Funding: This research was funded by Department of Science and Technology of An Giang province, Vietnam, grant number 373.2018.06.

Institutional Review Board Statement: Not applicable.

Informed Consent Statement: Not applicable.

Data Availability Statement: Not applicable.

Conflicts of Interest: The authors declare no conflict of interest.

\section{References}

1. Mathers, C.D.; Loncar, D. Projections of global mortality and burden of disease from 2002 to 2030. PLoS Med. 2006, 3, e442. [CrossRef]

2. Inzucchi, S.E. Oral antihyperglycemic therapy for type 2 diabetes: Scientific review. J. Am. Med. Assoc. 2002, 287, 360-372. [CrossRef]

3. Carlson, E.E. Natural products as chemical probes. ACS Chem. Biol. 2010, 5, 639-653. [CrossRef] [PubMed]

4. Sharma, N. Free radicals, antioxidants and disease. Biol. Med. 2014, 6, 214. [CrossRef]

5. Rates, S.M.K. Plants as source of drugs. Toxicon 2001, 39, 603-613. [CrossRef]

6. Kuna, L.; Jakab, J.; Smolic, R.; Raguz-Lucic, N.; Vcev, A.; Smolic, M. Peptic ulcer disease: A brief review of conventional therapy and herbal treatment options. J. Clin. Med. 2019, 8, 179. [CrossRef] [PubMed]

7. Casula, E.; Manca, M.L.; Manconi, M. An integrative review on the uses of plant-derived bioactives formulated in conventional and innovative dosage forms for the local treatment of damaged nasal cavity. Int. J. Pharm. 2021, 610, 121229. [CrossRef] [PubMed]

8. Dutta, T.; Paul, A.; Majumder, M.; Sultan, R.A.; Emran, T.B. Pharmacological evidence for the use of Cissus assamica as a medicinal plant in the management of pain and pyrexia. Biochem. Biophys. Rep. 2020, 21, 100715. [CrossRef]

9. Jumana, S.; Hasan, C.M.; Rashid, M.A. Antibacterial activity and cytotoxicity of Miliusa velutina. Fitoterapia 2000, 71, 559-561. [CrossRef]

10. Linh, T.C.; Trang, Đ.T.X. Đánh giá hoạt tính kháng oxy hóa và kháng đái tháo đường in vitro của các cao chiết từ lá cây cò sen (Miliusa velutina). Tạp chí Khoa học và công nghệ Đại học Thái Nguyên 2019, 207, 99-106. (In Vietnamese)

11. Trang, Đ.T.X.; Bui, H.L.T.; Tran, L.C.; Luu, D.T.; Nguyen, T.T. Antioxidant and hepatoprotective potentials of miliusa velutina stem bark extract. Sci. Technol. Dev. J.-Nat. Sci. 2020, 4, 633-642.

12. Promgool, T.; Kanokmedhakul, K.; Tontapha, S.; Amornkitbamrung, V.; Tongpim, S.; Jamjan, W.; Kanokmedhakul, S. Bioactive homogentisic acid derivatives from fruits and flowers of Miliusa velutina. Fitoterapia 2019, 134, 65-72. [CrossRef] [PubMed]

13. Kitzberger, C.S.G.; Smânia, A.; Pedrosa, R.C.; Ferreira, S.R.S. Antioxidant and antimicrobial activities of shiitake (Lentinula edodes) extracts obtained by organic solvents and supercritical fluids. J. Food Eng. 2007, 80, 631-638. [CrossRef]

14. Biswas, S.K.; Chowdhury, A.; Raihan, S.Z.; Muhit, M.A.; Akbar, M.A.; Mowla, R. Phytochemical investigation with assessment of cytotoxicity and antibacterial activities of chloroform extract of the leaves of Kalanchoe pinnata. J. Plant Physiol. 2012, 7, 41-46. [CrossRef] 
15. Singleton, V.L.; Orthofer, R.; Lamuela-Raventós, R.M. Analysis of total phenols and other oxidation substrates and antioxidants by means of folin-ciocalteu reagent. Methods Enzymol. 1999, 299, 152-178. [CrossRef]

16. Bag, G.C.; Devi, P.G.; Bhaigyabati, T. Assessment of total flavonoid content and antioxidant activity of methanolic rhizome extract of three Hedychium species of Manipur Valley. Int. J. Pharm. Sci. Rev. Res. 2015, 30, 154-159.

17. Sharma, O.P.; Bhat, T.K. DPPH antioxidant assay revisited. Food Chem. 2009, 113, 1202-1205. [CrossRef]

18. Nenadis, N.; Wang, L.F.; Tsimidou, M.; Zhang, H.Y. Estimation of scavenging activity of phenolic compounds using the ABTS •+ assay. J. Agric. Food Chem. 2004, 52, 4669-4674. [CrossRef]

19. Oyaizu, M. Studies on products of browning reaction. Antioxidative activities of products of browning reaction prepared from glucosamine. Jpn. J. Nutr. Diet. 1986, 44, 307-315. [CrossRef]

20. Piaru, S.P.; Mahmud, R.; Majid, A.M.S.A.; Nassar, Z.D.M. Antioxidant and antiangiogenic activities of the essential oils of Myristica fragrans and Morinda citrifolia. Asian Pac. J. Trop. Med. 2012, 5, 294-298. [CrossRef]

21. Benzie, I.F.F.; Strain, J.J. The ferric reducing ability of plasma (FRAP) as a measure of "antioxidant power": The FRAP assay. Anal. Biochem. 1996, 239, 70-76. [CrossRef] [PubMed]

22. Prieto, P.; Pineda, M.; Aguilar, M. Spectrophotometric quantitation of antioxidant capacity through the formation of a phosphomolybdenum complex: Specific application to the determination of vitamin E. Anal. Biochem. 1999, 269, 337-341. [CrossRef] [PubMed]

23. Rana, Z.H.; Alam, M.K.; Akhtaruzzaman, M. Nutritional composition, total phenolic content, antioxidant and $\alpha$-amylase inhibitory activities of different fractions of selected wild edible plants. Antioxidants 2019, 8, 203. [CrossRef]

24. Pujirahayu, N.; Bhattacharjya, D.K.; Suzuki, T.; Katayama, T. $\alpha$-Glucosidase inhibitory activity of cycloartane-type triterpenes isolated from indonesian stingless bee propolis and their structure-activity relationship. Pharmaceuticals 2019, 12, 102. [CrossRef]

25. Roginsky, V.; Lissi, E.A. Review of methods to determine chain-breaking antioxidant activity in food. Food Chem. 2005, 92, 235-254 [CrossRef]

26. Abu, F.; Mat Taib, C.N.; Mohd Moklas, M.A.; Mohd Akhir, S. Antioxidant properties of crude extract, partition extract, and fermented medium of Dendrobium sabin flower. eCAM 2017, 2017, 2907219. [CrossRef] [PubMed]

27. Kim, H.; Choi, H.K.; Moon, J.Y.; Kim, Y.S.; Mosaddik, A.; Cho, S.K. Comparative antioxidant and antiproliferative activities of red and white pitayas and their correlation with flavonoid and polyphenol content. J. Food Sci. 2011, 76, C38-C45. [CrossRef] [PubMed]

28. Chaudhari, G.M.; Mahajan, R.T. Comparative antioxidant activity of twenty traditional Indian medicinal plants and its correlation with total flavonoid and phenolic content. Int. J. Pharm. Sci. Rev. Res. 2015, 30, 105-111.

29. Kim, E.J.; Choi, J.Y.; Yu, M.R.; Kim, M.Y.; Lee, S.H.; Lee, B.H. Total polyphenols, total flavonoid contents, and antioxidant activity of Korean natural and medicinal plants. Korean J. Food Sci. Technol. 2012, 44, 337-342. [CrossRef]

30. Lucas-González, R.; Fernández-López, J.; Pérez-Álvarez, J.Á.; Viuda-Martos, M. Effect of particle size on phytochemical composition and antioxidant properties of two persimmon flours from Diospyros kaki Thunb. vars. Rojo Brillante'and 'Triumph'coproducts. J. Sci. Food Agric. 2018, 98, 504-510. [CrossRef]

31. Hayat, J.; Akodad, M.; Moumen, A.; Baghour, M.; Skalli, A.; Ezrari, S.; Belmalha, S. Phytochemical screening, polyphenols, flavonoids and tannin content, antioxidant activities and FTIR characterization of Marrubium vulgare L. from 2 different localities of Northeast of Morocco. Heliyon 2020, 6, e05609. [CrossRef] [PubMed]

32. Haq, S.H.; Al-Ruwaished, G.; Al-Mutlaq, M.A.; Naji, S.A.; Al-Mogren, M.; Al-Rashed, S.; Al-Mussallam, A. Antioxidant, anticancer activity and phytochemical analysis of green algae, Chaetomorpha collected from the Arabian Gulf. Sci. Rep. 2019, 9, 18906. [CrossRef] [PubMed]

33. Son, N.T. Genus Miliusa: A review of phytochemistry and pharmacology. Evid.-Based Complementary Altern. Med. 2019, 2019, 8314693.

34. Everette, J.D.; Bryant, Q.M.; Green, A.M.; Abbey, Y.A.; Wangila, G.W.; Walker, R.B. Thorough study of reactivity of various compound classes toward the Folin- Ciocalteu reagent. J. Agric. Food Chem. 2010, 58, 8139-8144. [CrossRef]

35. Ahmed, F.; Iqbal, M. Antioxidant activity of Ricinus Communis. Org. Med. Chem. Int. J. 2018, 5, 555667. [CrossRef]

36. Aryal, S.; Baniya, M.K.; Danekhu, K.; Kunwar, P.; Gurung, R.; Koirala, N. Total phenolic content, flavonoid content and antioxidant potential of wild vegetables from Western Nepal. Plants 2019, 8, 96. [CrossRef]

37. Adefegha, S.A.; Oboh, G. Inhibition of key enzymes linked to type 2 diabetes and sodium nitroprusside-induced lipid peroxidation in rat pancreas by water extractable phytochemicals from some tropical spices. Pharm. Biol. 2012, 50, 857-865. [CrossRef] [PubMed]

38. De Sousa, E.; Zanatta, L.; Seifriz, I.; Creczynski-Pasa, T.B.; Pizzolatti, M.G.; Szpoganicz, B.; Silva, F.R.M.B. Hypoglycemic effect and antioxidant potential of kaempferol-3,7-O- $(\alpha)$-dirhamnoside from Bauhinia forficata leaves. J. Nat. Prod. 2004, 67, 829-832. [CrossRef]

39. Hanamura, T.; Hagiwara, T.; Kawagishi, H. Structural and functional characterization of polyphenols isolated from Acerola (Malpighia emarginata DC.) fruit. Biosci. Biotechnol. Biochem. 2005, 69, 280-286. [CrossRef]

40. Kwon, Y.I.; Apostolidis, E.; Shetty, K. Inhibitory potential of wine and tea against $\alpha$-amylase and $\alpha$-glucosidase for management of hyperglycemia linked to type 2 diabetes. J. Food. Biochem. 2008, 32, 15-31. [CrossRef]

41. Tadera, K.; Minami, Y.; Takamatsu, K.; Matsuoka, T. Inhibition of $\alpha$-glucosidase and $\alpha$-amylase by flavonoids. J. Nutr. Sci. Vitaminol. 2006, 52, 149-153. [CrossRef] [PubMed] 
42. Gu, C.; Zhang, H.; Putri, C.; Ng, K. Evaluation of $\alpha$-Amylase and $\alpha$-Glucosidase Inhibitory Activity of Flavonoids. Int. J. Food Sci. Nutr. 2015, 2, 1-6. [CrossRef]

43. Mbhele, N.; Balogun, F.O.; Kazeem, M.I.; Ashafa, T. In vitro studies on the antimicrobial, antioxidant and antidiabetic potential of Cephalaria gigantea. Bangladesh J. Pharmacol. 2015, 10, 214-221. [CrossRef] 